\title{
16S Mitochondrial Ribosomal RNA
}

National Cancer Institute

\section{Source}

National Cancer Institute. 165 Mitochondrial Ribosomal RNA. NCI Thesaurus. Code C131261.

$16 \mathrm{~S}$ mitochondrial ribosomal RNA is encoded by the human MT-RNR2 gene. This ribonucleotide is involved in mitochondrial protein translation. 